\title{
MAJOR OXIDES GEOCHEMISTRY OF TOURMALINE FROM SELECTED GEM-MineRAL DEPOSITS IN SOUTHWESTERN NiGERIA
}

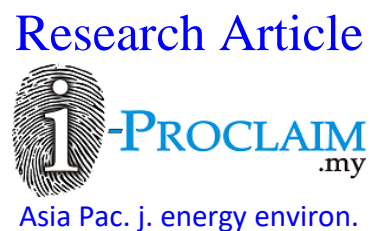

\author{
A. S. Olatunji ${ }^{1}$, Onawola Razak Jimoh ${ }^{2 *}$ \\ ${ }^{1}$ Department of Geology, University of Ibadan, Ibadan, NIGERIA \\ ${ }^{2}$ Department of Chemical and Geological Sciences, Al-Hikmah University, Ilorin, NIGERIA \\ *Email for Correspondence: rojges@ yahoo.com
}

Abstract

Tourmaline occurs in associations with other gem minerals such as beryl, topaz, garnet and kunzite alongside rock-forming minerals like quartz, feldspar and muscovite in various gem mineral deposits across southwestern Nigeria. These occurrences of tourmaline in varieties of colors resulting from its range in chemical compositions remain puzzling, more so when there is a lack of sufficient information on the chemistry of the Nigerian tourmalines. This study is aimed at the major oxides investigation of tourmalines from selected gem-mineral deposits in southwestern Nigeria and how the chemistry can be used to infer their environment and processes of mineralization. A total of 22 differently colored tourmaline samples obtained from different locations in southwestern Nigeria were prepared and analyzed, using the inductively coupled plasma - mass spectrometry (ICP-MS) to determine the elemental constituents. Komu and Ijero-Ekiti, being the two areas with highest concentrations of the study samples were specially chosen and mapped, at least to reveal the geology of some gem mineral deposits in the area. Results of the geochemical analysis of the tourmaline samples showed enrichment in $\mathrm{SiO} 2$ and $\mathrm{Al} 2 \mathrm{O} 3$, but depletion in the remaining major oxides. However, a few of the tourmaline samples showed unusual enrichment in $\mathrm{CaO}$, revealing the fact that the samples have crystallized from highly fractionated melt. The major oxide compositions of the tourmalines exhibited wide and distinct variations, especially in $\mathrm{SiO} 2, \mathrm{Al} 2 \mathrm{O} 3$ and $\mathrm{CaO}$, indicating magmatic origin for the southwestern Nigerian tourmalines. Similarly, the strong negative correlations observed between $\mathrm{CaO}$ and the oxides $\mathrm{Al} 2 \mathrm{O} 3, \mathrm{Na} 2 \mathrm{O}, \mathrm{K} 2 \mathrm{O}$ and $\mathrm{SiO} 2$ in the tourmaline samples, coupled with the relatively high $\mathrm{Fe} / \mathrm{Fe}+\mathrm{Mg}$ ratio, averaging 0.89 ,clearly reinforced magmatic sourcing for the tourmalines. Almost all the southwestern tourmaline samples plot in the predefined field of Li-rich granitoidpegmatites and aplites in the $\mathrm{Al}-\mathrm{Fe}-\mathrm{Mg}$ and $\mathrm{Ca}-\mathrm{Fe}-\mathrm{Mg}$ plots. Southwestern Nigerian tourmalines are thus magmatic in origin with their chemistry reflecting control by host rocks and granitic-pegmatitic fluid. The study also revealed that the intensity of coloration in tourmalines can be linked to the presence or otherwise of iron concentration. The iron content varies directly and proportionately with the depth of color in the greens, and inversely in the pinks and reds.

Key words

Southwestern Nigeria, Tourmaline, Major oxides, Pegmatite, Host rock, Magmatic origin

This article is is licensed under a Creative Commons Attribution-NonCommercial 4.0 International License.

Attribution-Non Commercial (CC BY-NC) license lets others remix, tweak, and build upon work non-commercially, and although the new works must also

acknowledge \& be non-commercial.

\section{INTRODUCTION}

Tourmaline, a group of boron aluminum cyclosilicate mineral, with a typical complex chemical formula $\mathrm{Na}(\mathrm{Mg}, \mathrm{Fe})_{3} \mathrm{Al}_{6}\left(\mathrm{BO}_{3}\right)_{3}\left(\mathrm{Si}_{6} \mathrm{O}_{18}\right)(\mathrm{OH})_{4}$, is categorized as a semi-precious gem mineral with special beauty (color) and physical properties making it suitable for adornment and decorative purposes. Tourmaline varies greatly in composition, and consequently the colour varies with the chemical composition of the crystals. Its multitude of colors and hardness combine to make tourmaline a spectacular gemstone (Pezzotta and Laurs, 2011). Natural gem minerals being constituents of rocks are formed through various geological processes. Tourmaline therefore occurs in a variety of geological environments, generally found as minor accessory phases in rocks such as granitic pegmatites, low- to high-grade metamorphic rocks and clastic sedimentary rocks. However, hydrothermal 
depositions comprise some of the most common and diverse occurrences worldwide. In Nigeria, particularly in the southwest, the most common and characteristic occurrences of euhedral gem tourmalineare in pegmatites and as detrital grains in alluvial deposits, where they must have been deposited after weathering has released them from their parent pegmatites. Gem quality tourmalines crystallize almost exclusively from rare-elements and LCT-family pegmatites. Recent work has shown that a number of tourmaline species such as schorl, elbaite, liddicoatite, magnesiofoitite, rossmanite and olenite occur in these types of pegmatites (Hawthorne et al., 1993; Selway et al., 1998; MacDonald et al., 1993). In most gemstone deposits of southwestern Nigeria, crystals of different colors of tourmaline occur in miarolitic cavities within granitic pegmatites and along the contacts between these pegmatites and their host (usually mafic) rocks, frequently associated with other gem minerals such as beryl, topaz, garnet, kunzite and amethyst, alongside other rock-forming minerals such as feldspars, quartz and micas. Prominent locations in southwestern Nigeria where various colors of tourmaline are found and currently being exploited include Komu, Ijero-Ekiti, Ofiki and Oro.

With the formula $\mathrm{XY}_{3} \mathrm{Z}_{6}\left(\mathrm{BO}_{3}\right)_{3} \mathrm{Si}_{6} \mathrm{O}_{18}(\mathrm{O}, \mathrm{OH}, \mathrm{F})_{4}$, the tourmaline group is one of the most chemically variable silicates, having many recognized mineral species (Hawthorne and Henry, 1999) and an extremely wide range of cation sizes and charges that can occupy the $\mathrm{X}, \mathrm{Y}$, and $\mathrm{Z}$ sites. Added to these properties, the large P-T stability field of tourmaline, its propensity to develop and retain chemical zoning, and its resistance to alteration and weathering, all make tourmaline an excellent mineral archive and therefore a good indicator mineral of its environment of deposition. Tourmaline's complex composition reflects changes in its chemical and physical environment which, combined with its refractory nature and wide range of stability, makes it well-suited to explore the conditions under which it formed (Henry and Guidotti, 1985). A tourmaline's large stability range, in both pressure and temperature, facilitates its widespread occurrence. Moreover, tourmaline has a crystal structure that accommodates major and trace elements of widely varying ionic charge and radius, making it an excellent monitor of the major and traceelement make-up of its local environment of growth. No known study is available in this part of the world, on the use of tourmalines in the compositional and/or evolutional study of its host environment, particularly its host pegmatite. In southwestern Nigeria, tourmaline mineralizations are widespread, occurring in many geologic settings but limited geological environments with widely varying types of mineral assemblages and chemical compositions, making this area an exceptional locality for studying controls on tourmaline chemistry. The study of tourmaline in these settings has the potential to constrain the origin(s) of this puzzling style of mineralization and can yield insights on the diversity of conditions under which tourmaline forms, thus giving insight into the evolutional history and composition of the host rock, particularly the parent pegmatite. Consequently, tourmaline could be an extremely useful petrogenetic indicator mineral if sufficient background information is attained so that the chemical signatures of tourmaline could be properly interpreted. This required a significant amount of allied investigations of tourmaline in disparate fields, which this study intends to undertake. This study therefore seeks to investigate the major oxide compositions of some southwestern Nigeria Tourmalines and to use the information obtained therefrom to infer the chemical composition and evolutional history of the host rocks.

\section{Materials AND Methods}

The study involved systematic geological mapping of two areas, Komu and Ijero-Ekiti, which contain majority of the studied samples, at least to ascertain the geology of some tourmaline deposits in southwestern Nigeria. Twenty-two samples of various colors of tourmaline, including rubellite, elbaite, dravite, indicolite and schorl (Table 1, Fig. 1) were obtained at different mining sites in southwestern Nigeria and prepared for geochemical analysis. Each of the crystal was inspected for clarity, zoning, and surface deposit. It was then crushed by wrapping carefully in a paper and striking it with a hammer. This was necessary to avoid any iron contamination which might in any way develop. The pieces thus obtained were selected individually using a 10 power magnifying lens. The particles were handled by tweezers to avoid contaminations. The selected particles were then ground in a thoroughly cleaned new agate mortar. The crushing process was continued until the tourmalines were reduced to fine-grained powder. The powder thus obtained was again examined with a magnifying lens and any suspicious particles were removed.

The geochemical analyses of the twenty-two (22) prepared samples of tourmaline from different locations in the study area were done at ACME Laboratories in Vancouver, Canada. Major elements concentrations were determined by $\mathrm{LiBO}_{2}$ fusion and Inductively Coupled Plasma - Mass Spectrometry (ICP-MS). An ICP-MS technique combines a high-temperature ICP (Inductively Coupled Plasma) source with a mass spectrometer. The ICP source converts the atoms of the elements in the sample to be analyzed to ions which are then separated and detected by the mass spectrometer. The sample is typically introduced into the ICP plasma as an aerosol, either by aspirating a liquid or dissolved solid sample into a nebulizer or using a laser to directly convert solid samples into an aerosol. Once the sample aerosol is introduced into the ICP torch, it is completely dissolved and the elements in the aerosol are converted first into gaseous atoms and then ionized towards the end of the plasma. Once the elements in the sample are converted into ions, they are then brought into the mass spectrometer via the interface cones. The interface region 
in the ICP-MS transmits the ions traveling in the argon sample stream at atmospheric pressure into the low pressure region of the mass spectrometer. Once the ions enter the mass spectrometer, they are separated by their mass-tocharge ratio. They must then be detected or counted by a suitable detector which fundamental purpose is to translate the number of ions striking the detector into an electrical signal that can be measured and related to the number of atoms of that element in the sample via the use of calibration standards.

\section{Geological Setting}

Nigeria is underlain by three major litho-petrological units, the Basement Complex (Pan-African and older (Precambrian), $\geq 600 \mathrm{Ma}$ ), Younger Granites (Jurassic, 200 - $145 \mathrm{Ma}$ ) and Sedimentary Basins (Cretaceous to Recent, $\leq$ $145 \mathrm{Ma}$ ). The study area which lies within the southwestern part of Nigeria is mainly underlain by crystalline rocks, collectively referred to as the Southwestern Nigerian Basement Complex. The Basement Complex of Nigeria, of which the Southwestern Nigeria Basement Complexis part, occupies about half the landmass of the country, Nigeria and it is a polycyclic terrain with a complex geologic history as a result of the different episodes of rock formation spanning Archean to Lower Proterozoic (Fig. 2). It forms a part of the African crystalline shield which occurs within the Pan African mobile belt that lies between the West African and Congo Cratons and south of the Tuareg Shield (Black, 1980). The Pre-Cambrian rocks consist predominantly of folded gneisses, schist and quartzite into which have been emplaced granitic and to a lesser extent, more basic materials. Three principal subdivisions are recognizable within the Basement Complex. Elueze (2000) gave these subdivisions as:-

- The ancient migmatite gneiss complex,

- The Schist belts, and

- The Pan African plutonic series.

Themigmatite gneiss complexis the most widespread, making up about $60 \%$ of the surface area of the Nigerian Basement Complex (Rahaman and Ocan, 1978) and it is therefore generally considered as the basement complex sensu strict (Rahaman, 1988; Dada, 2006). It has a heterogeneous assemblage comprising migmatites, orthogneises, paragneisses, granite-gneiss and a series of basic and ultra basic metamorphosed rocks. Petrographic evidence indicates that the Pan-African reworking led to re-crystallization of many of the constituent minerals of the Migmatite - Gneiss Complex by partial melting with majority of the rock types displaying medium to upper amphibolites facies metamorphism. The gneiss-migmatites have yielded Achaean and Proterozoic ages (Annor, 1995; Okonkwo and Ganev, 2012) and bears imprints of the Liberian (ca. 2700Ma), Eburnean (ca2000Ma) and Pan African (ca. 600Ma) tectonic events (Oversby, 1975; Turner, 1983,Rahaman, 1988, Dada, 1998).

Table 1: Studied tourmaline samples obtained from various locations in southwestern Nigeria

\begin{tabular}{|c|c|c|c|c|}
\hline Sample & Location & Mining site & Colour & Variety \\
\hline M001 & Komu & Abuja leather & Pink & Rubellite \\
\hline M002 & Komu & Abuja leather & Pinkish-red & Rubellite \\
\hline M003 & Komu & Abuja leather & Green & Verdelite \\
\hline M004 & Komu & Loton turawa & Blue & Indicolite \\
\hline M005 & Komu & Abuja leather & Yellow & Elbaite \\
\hline M006 & Komu & Abuja leather & Lemon yellow & Elbaite \\
\hline M007 & Komu & Abuja leather & Dark blue & Indicolite \\
\hline M008 & Ofiki & Budo Are & Purple & Elbaite \\
\hline M009 & Komu & Abuja leather & Yellow green & Elbaite \\
\hline M010 & Komu & Abuja leather & Brown & Dravite \\
\hline M011 & Komu & Ajet & Green & Verdelite \\
\hline M012 & Komu & Loton turawa & Grey & Elbaite \\
\hline M013 & Ofiki & Budo-Are & Orange & Elbaite \\
\hline M014 & Ijero & Oke-Kusa & Green blue & Indicolite \\
\hline M015 & Ijero & Oke-Kusa & Light blue & Indicolite \\
\hline M016 & Ijero & Oke-Kusa & Green & Verdelite \\
\hline M017 & Ijero & Oke-Kusa & Yellow green & Elbaite \\
\hline M018 & Ijero & Oke-Kusa & Green blue & Indicolite \\
\hline M019 & Oro & Ijomu-Oro & Dark blue & Indicolite \\
\hline M020 & Oro & Ijomu-Oro & Dark green & Verdelite \\
\hline M021 & Iganna & Iganna & Black & Schorl \\
\hline M022 & Ijero & Ijero & Blue & Indicolite \\
\hline
\end{tabular}




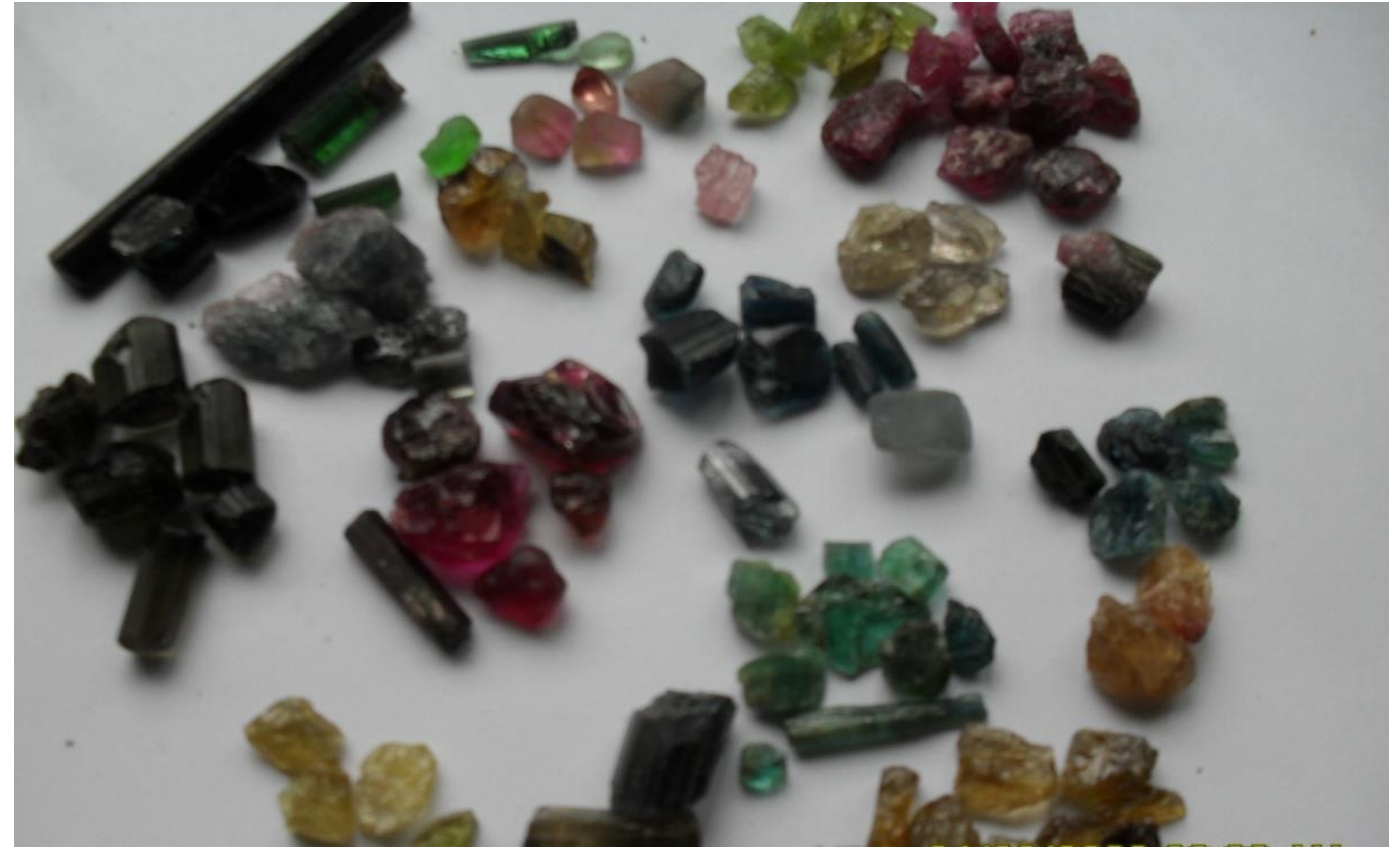

Figure 1: Studied southwestern Nigerian tourmaline samples

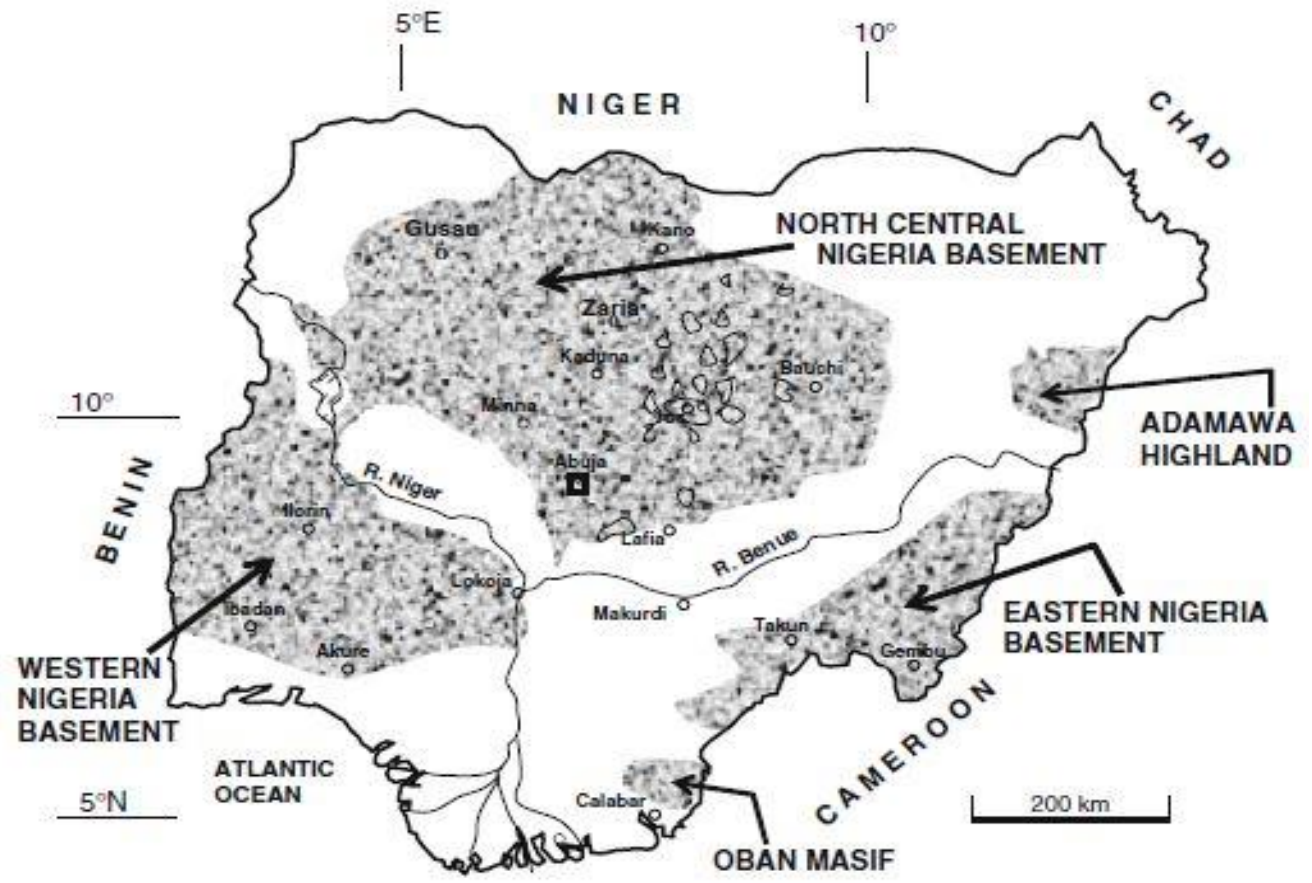

Figure 2: Geological map of Nigeria, showing the Basement Complex (after Obaje, 2009)

The Schist belts, which are mainly N-S to NNE-SSW trending are considered to be Upper Proterozoic supracrustal assemblages of low to medium grade meta-sedimentary (and minor volcanic) rocks which have been in-folded into the presumably oldermigmatite-gneiss complex (Turner,1983). The litho logical variations of the schist belts include quartzites, amphibolites, pelitic and mica-schists, calc-silicate rocks, marbles, phyllites, meta-conglomerate iron formations and subordinate meta-igneous rocks (Elueze, 1992).

The Pan African plutonic series, termed the Older Granites occur intricately associated with the Migmatite-Gneiss Complex and the Schist Belts into which they generally intruded and are believed to have been emplaced during the Pan-African orogeny (Harper et al, 1973).The Pan-African intrusive suite comprises mainly granites and granodiorite, with subordinate pegmatite and Aplites. Associated rocks include charnockites, syenites, tonalites, adamellites, quartz monzonites and gabbro plus extrusive and hypabyssal bodies, notably dolerite dikes believed to belong to the terminal stage of the Pan-African orogenic event in Nigeria (Olarewaju, 1999). 


\section{LOCAL GEOLOGY}

The two study areas, Komu and Ijero-Ekiti arelithologically similar, being underlain by amphibole and pelitic schists which have been intruded by pegmatites of various forms. Komu study area, which lies between latitudes $8^{\circ} 16^{\prime} 12^{\prime \prime} \mathrm{N}$ and $8^{\circ} 17^{\prime} 29^{\prime \prime} \mathrm{N}$ and longitudes $2^{\circ} 59^{\prime} 18^{\prime \prime} \mathrm{E}$ and $3^{\circ} 01^{\prime} 07^{\prime \prime} \mathrm{E}$ is mainly underlain by amphibole and pelitic schists which have been mostly intruded semi-discordantly by pegmatites (Fig. 3). Field evidence showed observable lateral compositional and textural variations of the schist. There is an increase in the quartzo-feldspathic content and a decrease in the amphibole content of the rock towards the west, hence more of the outcrops are preserved in this axis while in the eastern part,the area is devoid of any appreciable rock exposures due to intense weathering of the schist. Rocks are rarely exposed in the central portion, except in mining excavations and along stream channels. The Komu schist is part of the schist belt, a member of the Precambrian Basement Complex of Nigeria comprising low grade metasediments-dominated belts trending N-S, which are best developed in the western half of Nigeria (Annor et al., 1996). Like the schist belt, the Komu schists have a general N-S strike direction and dips moderately to steeply $\left(60^{\circ}-80^{\circ}\right)$.

In Komu, sporadic occurrences of pegmatites are widespread, intruding the older schists. In most instances, they occur aspegmatitic dikes making visible contacts with the older rock bodies, while in some others they are found as intrusive bodies forming isolated plutons within the study area. Thus two lithologically and chronologically different groups of Precambrian pegmatites are distinguishable in the area. The simple, usually barren massive quartz-microcline pegmatites with minor muscovite and accessory tourmalines, which usually occur as isolated intrusive bodies and the complex NNESSW trending, tourmaline-bearing pegmatites generally revealed to have intruded discordantly the amphibole schist as dikes and veins of various width and mainly observable in most mining excavations in the study area.

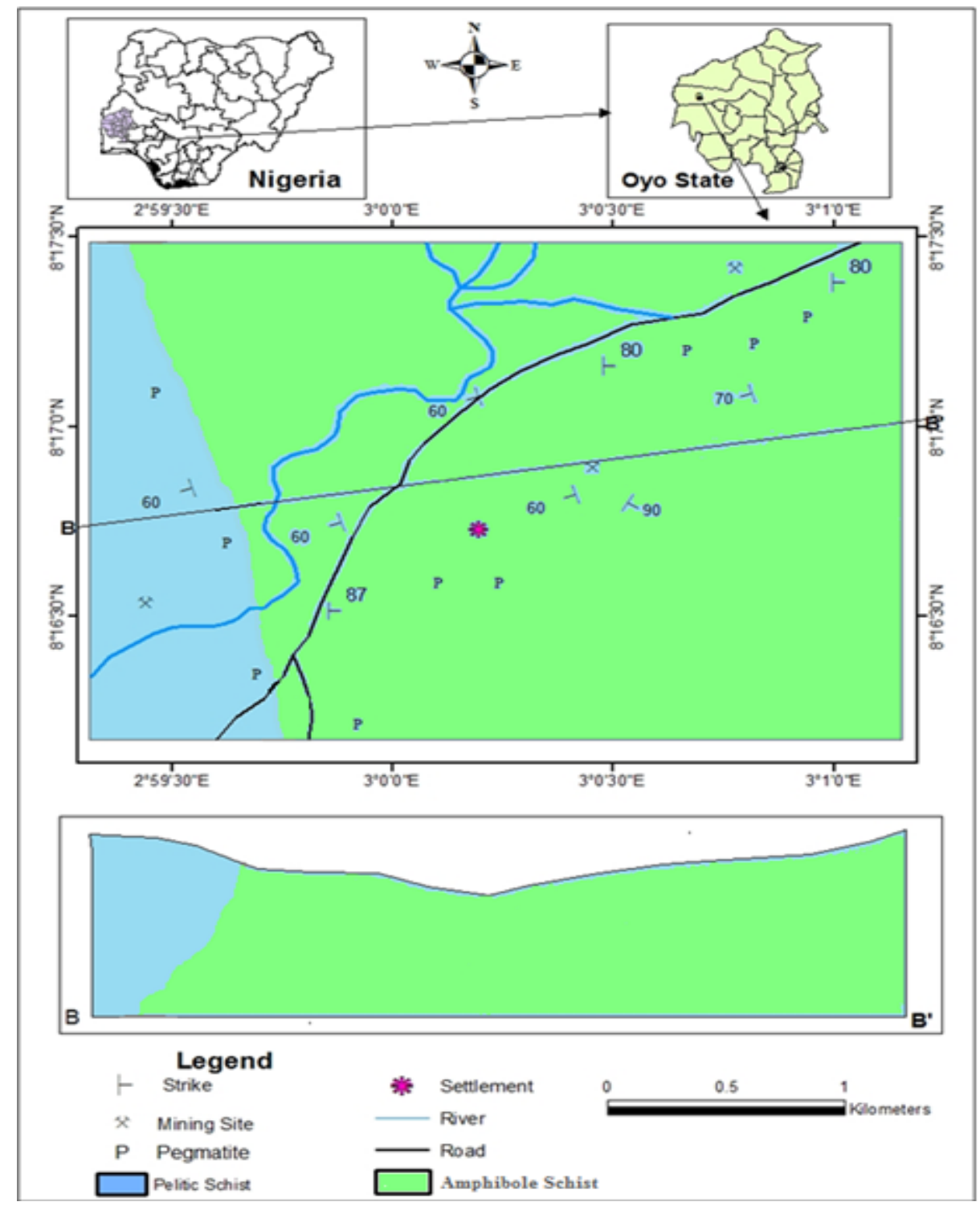

Figure 3: Geological map of Komu study area 
The tourmaline-bearing pegmatite has been described by Dada (2006) as a member of the felsic dikes that are associated with Pan African granitoids on the terrane. They belong tothe undeformed acid and basic dikes believed to be late to posttectonic Pan African, cross-cutting the Migmatite-Gneiss Complex, the Schist Belts and the Older Granites. This pegmatite field is therefore believed to be part of the late Pan African rare metals granitic pegmatites (Jacobson and Webb, 1946; Wright, 1970). They are younger than the simple massive quartz - microcline pegmatites which are usually associated with and therefore part of the Older Granite. Geochronological data from previous works ( $\mathrm{Rb}-\mathrm{Sr}$ whole-rock and U-Pb zircon) of Pan-African granitoids intruding the reactivated Archean to Lower Proterozoic crust of central and southwestern Nigeria showed that intrusive magmatic activity in these areas lasted from at least 630 to $530 \mathrm{Ma}$ (van Breemen et al., 1977; Rahaman et al., 1983; Dada etal., 1987; Matheis and Caen-Vachette, 1983; Umeji and Caen-Vachette, 1984; Akande and Reynolds, 1990).An older Pan African magmatic event in Southwestern Nigeria has however been reported by the obtained U-Pb Zircon age of $709+27 /-19$ for pegmatites in Ede (Adetunji et al., 2016). Results of the rock ages showed that the pegmatities' emplacement in southwestern Nigeria occurred mainly after the peak of the Pan-African orogenic event in this area.The end of the Pan-African tectonic event is marked by a conjugate fracture system of the strike-slip faults (Ball, 1980). Gold and rare-metal pegmatites' mineralization is closely associated with the fractures in the Pan-African belt (Kuster, 1990; Ekweme and Matheis, 1995; Garba, 1992, 2003).

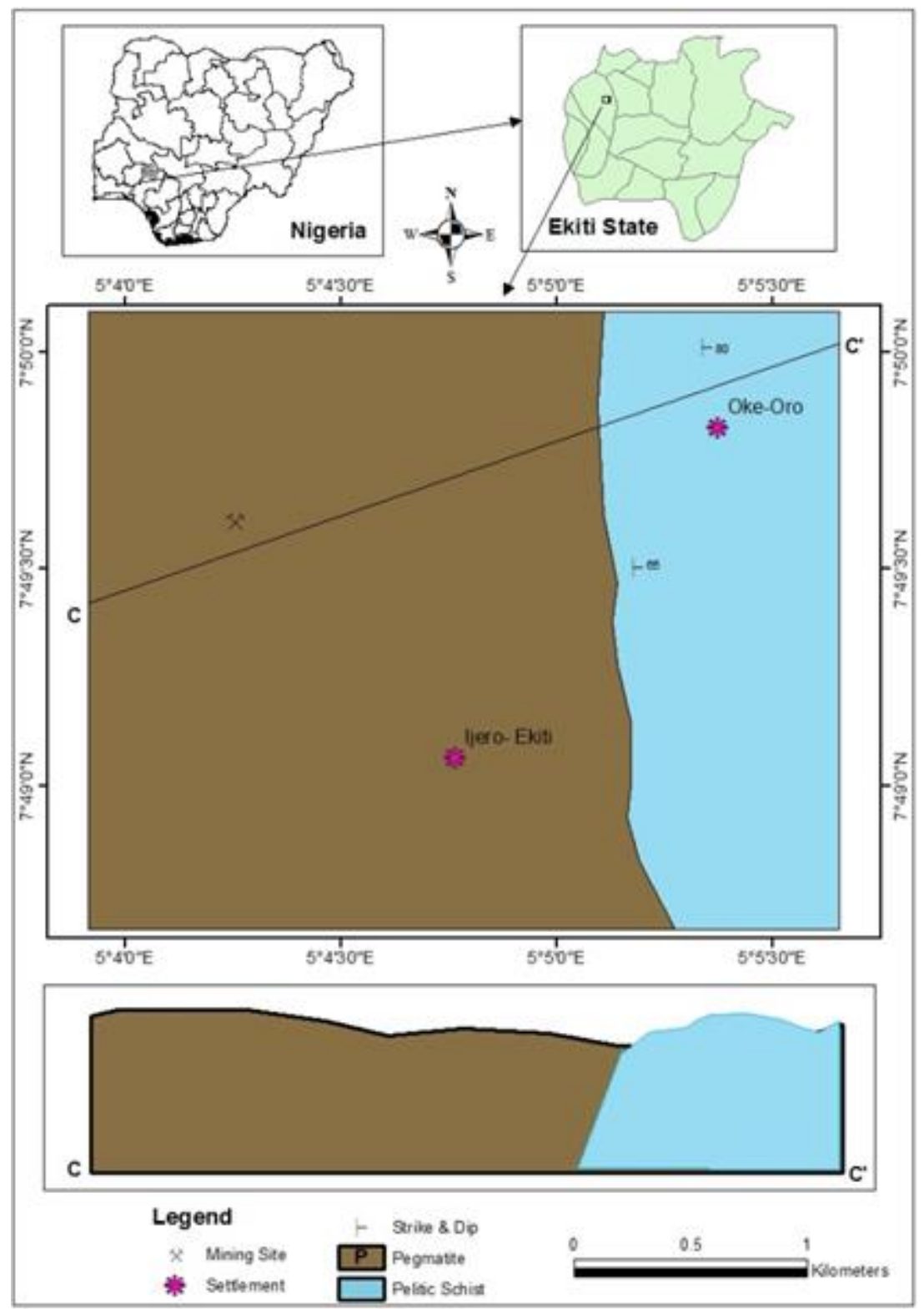

Figure 4: Geological map of Ijero-Ekiti study area

The Ijero study area lies within latitudes $7^{0} 48^{\prime} 36^{\prime \prime}$ to $7^{0} 50^{\prime} 06^{\prime \prime}$ and longitudes $5^{0} 03^{\prime} 54^{\prime \prime}$ to $5^{0} 05^{\prime} 42^{\prime \prime}$. The lithology of the area is mainly characterized by pegmatites and meta-sedimentary rocks, consisting of dark colored amphibole and quartz-feldspathic pelitic schist, intercalated with amphibolite and some quartzites. The amphibole schists, 
observed in the central and western portions are highly weathered and therefore rarely exposed, with only a few bands of the strongly foliated weathered dark green rock feebly observed along stream channels and road side cuttings. The amphibole schist and amphibolite observed mainly in the western and central portions of the area have been heavily intruded by the tourmaline-bearing Precambrian pegmatites, making the older rocks sparsely seen, falsely revealing the pegmatite as the dominant rock type in the areas. However, at the eastern part underlain mainly by the quartz-feldspathic pelitic schist, the rocks are well exposed (Fig. 4). The Ijero pegmatites which cover more than two-thirds of the total landmass are most times tabular and expansive in nature. This pegmatite is believed to be part of the mineralized 400km NE-SW trending Nigeria pegmatites which belong to the terminal stage of PanAfrican magmatism (Rahaman et al., 1988).The schists have foliations striking in the north-south direction and dipping moderately to steeply $\left(60^{\circ}-70^{\circ}\right)$ westwards and the mineral alignments seem conformable with the foliation planes of the adjacent schistose rocks.

\section{RESULTS AND Discussion}

Results of the southwestern Nigerian tourmalines showed enrichments in $\mathrm{SiO}_{2}$ and $\mathrm{Al}_{2} \mathrm{O}_{3}$, but depletions in the remaining oxides (Table 2). $\mathrm{SiO}_{2}$ concentrations ranged from $44.14 \%$ (M004) to 93.28\% (M013) with a mean value of $86.36 \%$, while $\mathrm{Al}_{2} \mathrm{O}_{3}$ ranged from $0.57 \%$ (M004) to $12.69 \%$ (M019) with a mean value of $7.8 \%$. Wide compositional

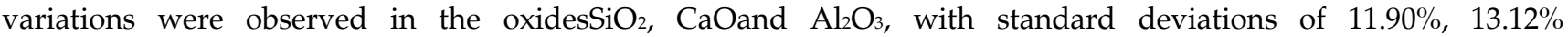
and $2.70 \%$ respectively, while the remaining oxides showed very narrow variability (Table 3 ). The wide compositional variability of the three oxides has resulted from the compositional heterogeneity of the mineralizing fluids and diversity in geologic settings and chemistry of the host rock environments of crystallization of the tourmalines. Previous studies have shown that the composition of tourmaline typically reflects the environment in which it crystallized (Henry and Guidotti, 1985; Slack, 1996). CaO concentrations ranged from 0.01\% (M005) to 54.99\% (M004) with a mean value of $4.13 \%$. The sear extremely contrasting values, which may essentially be due to the huge contrast in geological backgrounds of the environments of crystallization of the respective tourmaline samples, most probably brought about by the compositional heterogeneity of their host rocks. $\mathrm{Al}_{2} \mathrm{O}_{3}$ is adequately concentrated in the southwestern tourmaline, since an adequate concentration of $\mathrm{Al}$ is necessary and required for tourmaline crystallization, as Grew (1996) proved that in highly alkaline and silica- or aluminum-under saturated conditions, tourmaline growth is inhibited, and other borosilicates form instead. It therefore follows that maximum concentrations of the oxides $\mathrm{SiO}_{2}$ and $\mathrm{Al}_{2} \mathrm{O}_{3}$ are required for tourmaline crystallization in an environment.

The compositional variations of the oxidesSiO $\mathrm{S}_{2}, \mathrm{CaO}$ and $\mathrm{Al}_{2} \mathrm{O}_{3}$ do not seem to be apparently responsible for any difference in the physical properties, particularly the color of tourmalines, but they are observed to adversely influence the distribution of other major oxides. An inverse relationship seems to exist between $\mathrm{SiO}_{2}$ andCaOon one side, as revealed in samples M004 and $\mathrm{M} 012$ and on the other side between $\mathrm{Al}_{2} \mathrm{O}_{3}$ and $\mathrm{CaO}$. Relatively low $\mathrm{SiO}_{2}$ values of $44.14 \%$ and $62.47 \%$ were encountered in samplesM004 and M012 as opposed to their enormous enrichments of $54.99 \%$ and $31.00 \%$ in $\mathrm{CaO}$ respectively, reflecting the fact that the presence of $\mathrm{CaO}$ has negative effects on $\mathrm{SiO}_{2}$ concentrations.Kabata-Pendias (2001) indeed reported the existence of several interferences between $\mathrm{Si}$ and other ions such as $\mathrm{P}^{5+}, \mathrm{Al}^{2+}, \mathrm{Ca}^{2+}$ and $\mathrm{Fe}^{2+}$ occurring in environments that modify its behavior. The chemical compositions of these two tourmaline samples, M004 and M012, sourced from Lotonturawa mining site in Komu can therefore be said to be distinctly different from the others, indicating that the mineralizing fluid from which these samples have crystallized must have resulted from highly fractionated melt. It can therefore be deduced that the fluid responsible for the formation of the two samples was enriched in $\mathrm{Ca}$ but deficient in $\mathrm{Si}$. The enrichment or depletion of any element(s) in various gem fields reflects the geology, geochemistry and mineralogy of the source regions. Since tourmaline compositions reflect both the host rock and fluid source characteristics and are strongly controlled by the mineral assemblage, the high $\mathrm{CaO}$ concentrations in these two tourmaline samples might have resulted either from possible high Ca-plagioclase (anorthite) content of the pegmatite housing the tourmaline minerals or could be due to contaminations from the host rock that is rich in such mafic minerals like pyroxene and amphibole.

$\mathrm{FeO}$ composition in the southwestern Nigerian tourmaline samples ranged from $0.01 \%$ to $2.1 \%$ with a mean value of $0.76 \%$. Whereas $\mathrm{FeO}$ was found to be highly depleted in samples M001(0.01\%) and M002 $(0.01 \%)$ which are pink and pinkish-red tourmalines respectively, it was significantly present in samples M003 (0.87\%), M007 (1.89\%), M009 $(0.72 \%)$, M011 (0.99\%), M014 (1.26\%), M016 (1.11\%), M017 (0.89\%), M019 (2.10\%), M020 (1.99\%), M021 (2.02\%) which are emerald green, dark blue, yellow, green, green-blue, green, yellow-green, dark blue, and black coloured tourmalines respectively (Table 2). While samples which appear green and dark have higher values of $\mathrm{FeO}$, the values are low in samples that are pink and pale in color. It therefore implies that the variation in $\mathrm{FeO}$ concentrations of the samples have adverse effects on type and intensity of colouration in tourmalines. The darker greens had the most iron, becoming less in the lighter shades and completely undetected in the lightest pink. Samples M021 (2.02\%), a schorl and M019 (2.1\%), dark blue tourmaline have the highest concentrations of Iron oxide. The results showed $\mathrm{FeO}$ in greater concentration in the green and black tourmalines, whereas, on the contrary it was observed to be low in samples M005 (0.04\%), M008 
$(0.08 \%)$ and M013 (0.03\%), which may most likely be responsible for their pale colours of yellow, purple and orange respectively. The dravite, also follows the same trend as other tourmalines with respect to corresponding colors; Fe content again controls the intensity, with hues ranging from brown sample, M010 (0.48\%)) down to lemon yellow sample M006 (0.27\%), to yellow sample, M005 $(0.04 \%))$ and then to orange M013(0.03\%)). The results established that the $\mathrm{FeO}$ content varies directly and proportionately with the depth of color in the greens, and inversely in the pinks and reds, being totally absent, or, if present, only in extremely minute traces in the reds. This is in conformity with widely reported works, the foremost one being Deer et al. (1966), who acknowledged the main controlling factor for color in tourmaline to be the presence or absence of Fe. Dunn (1977) actually established a relationship between a decrease in Fe content and a decrease in color intensity, an assertion similarly supported by this study.

$\mathrm{TiO}_{2}, \mathrm{Na}_{2} \mathrm{O}, \mathrm{K}_{2} \mathrm{O}$, and $\mathrm{MgOwere}$ found to remain fairly constant in all the samples analyzed. $\mathrm{TiO}_{2}$ is believed to be a substitute for iron and silicon (Hawthorne and Henry, 1999).Although $\mathrm{Fe}^{2+}=>\mathrm{Ti}^{4+}$ charge-transfer has been cited as the cause for blue colour in kyanite and dumortierite (Parkin et al., 1977; Platonov et al., 2000), it is not likely true for tourmalines. This is because $\mathrm{TiO}_{2}$ has been observed to be constantly of low values throughout the analyzed tourmaline samples, including the blues while the blue tourmaline samples are found to be relatively rich in $\mathrm{FeO}$, suggesting that $\mathrm{Fe}$ is probably among the primary chromophores responsible for deep blue colors in tourmalines. $\mathrm{K}_{2} \mathrm{O}$ is evenly distributed in all the samples analyzed, but found to be a little more enriched in sample M002 (0.52\%). The analyzed samples showed poor enrichment in $\mathrm{P}_{2} \mathrm{O}_{5}$, except samples M008 and M013, sourced from the same site which showed relatively high values of $1.33 \%$ and $0.51 \%$ respectively, confirming an entirely different environment of deposition and mineralizing fluid for the samples.

Table 2: Major oxide compositions of studied tourmaline samples from southwestern Nigeria

\begin{tabular}{|c|c|c|c|c|c|c|c|c|c|c|c|}
\hline Sample & $\begin{array}{l}\text { Sample } \\
\text { Source }\end{array}$ & Sample colour & $\begin{array}{c}\mathrm{SiO}_{2} \\
(\%)\end{array}$ & $\begin{array}{l}\mathrm{FeO} \\
(\%)\end{array}$ & $\begin{array}{c}\mathrm{CaO} \\
(\%)\end{array}$ & $\begin{array}{c}\mathrm{P}_{2} \mathrm{O}_{5} \\
(\%)\end{array}$ & $\begin{array}{c}\mathrm{MgO} \\
(\%)\end{array}$ & $\begin{array}{c}\mathrm{TiO}_{2} \\
(\%)\end{array}$ & $\begin{array}{c}\mathrm{Al}_{2} \mathrm{O}_{3} \\
(\%)\end{array}$ & $\begin{array}{c}\mathrm{Na}_{2} \mathrm{O} \\
(\%)\end{array}$ & $\begin{array}{c}\mathrm{K}_{2} \mathrm{O} \\
(\%)\end{array}$ \\
\hline M001 & Komu & Pink & 93.15 & 0.01 & 0.06 & 0.02 & 0.01 & 0.01 & 6.33 & 0.31 & 0.13 \\
\hline M002 & Komu & Pinkish red & 91.39 & 0.01 & 0.07 & 0.03 & 0.01 & 0.01 & 7.59 & 0.38 & 0.52 \\
\hline M003 & Komu & Emerald Green & 89.85 & 0.87 & 0.31 & 0.23 & 0.01 & 0.01 & 7.90 & 0.67 & 0.16 \\
\hline M004 & Komu & Blue & 44.14 & 0.13 & 54.99 & 0.01 & 0.01 & 0.08 & 0.57 & 0.04 & 0.05 \\
\hline M005 & Komu & Yellow & 92.21 & 0.04 & 0.01 & 0.01 & 0.01 & 0.07 & 6.97 & 0.58 & 0.13 \\
\hline M006 & Komu & Lemon yellow & 92.35 & 0.27 & 0.10 & 0.01 & 0.01 & 0.01 & 6.63 & 0.47 & 0.17 \\
\hline M007 & Komu & Dark blue & 84.84 & 1.89 & 0.07 & 0.01 & 0.01 & 0.02 & 11.79 & 1.01 & 0.28 \\
\hline M008 & Ofiki & Purple & 92.50 & 0.08 & 1.43 & 1.33 & 0.01 & 0.01 & 4.00 & 0.51 & 0.14 \\
\hline M009 & Komu & Yellow green & 91.09 & 0.72 & 0.20 & 0.02 & 0.12 & 0.04 & 6.91 & 0.69 & 0.22 \\
\hline M010 & Komu & Brown & 87.94 & 0.48 & 0.39 & 0.22 & 0.01 & 0.03 & 9.82 & 0.87 & 0.25 \\
\hline M011 & Komu & Green & 88.13 & 0.99 & 0.41 & 0.01 & 0.01 & 0.02 & 9.60 & 0.65 & 0.20 \\
\hline M012 & Komu & Grey & 62.47 & 0.23 & 31.00 & 0.01 & 0.01 & 0.05 & 5.80 & 0.33 & 0.11 \\
\hline M013 & Ofiki & Orange & 93.28 & 0.03 & 0.85 & 0.51 & 0.01 & 0.02 & 4.87 & 0.32 & 0.12 \\
\hline M014 & Ijero & Green blue & 89.91 & 1.26 & 0.04 & 0.02 & 0.01 & 0.01 & 7.93 & 0.67 & 0.16 \\
\hline M015 & Ijero & Light blue & 91.72 & 0.35 & 0.13 & 0.01 & 0.01 & 0.01 & 7.20 & 0.45 & 0.14 \\
\hline M016 & Ijero & Green & 87.86 & 1.11 & 0.13 & 0.01 & 0.05 & 0.01 & 9.88 & 0.77 & 0.19 \\
\hline M017 & Ijero & Yellow green & 88.62 & 0.89 & 0.18 & 0.03 & 0.05 & 0.02 & 9.37 & 0.68 & 0.16 \\
\hline M018 & Ijero & Green blue & 90.50 & 0.59 & 0.15 & 0.06 & 0.01 & 0.01 & 7.93 & 0.55 & 0.19 \\
\hline M019 & Oro & Dark blue & 83.73 & 2.10 & 0.07 & 0.01 & 0.01 & 0.02 & 12.69 & 1.14 & 0.24 \\
\hline M020 & Oro & Dark green & 85.25 & 1.99 & 0.14 & 0.01 & 0.01 & 0.03 & 11.37 & 0.94 & 0.27 \\
\hline M021 & Iganna & Black & 87.55 & 2.02 & 0.08 & 0.03 & 0.17 & 0.03 & 9.20 & 0.74 & 0.18 \\
\hline M022 & Ijero & Blue & 91.36 & 0.66 & 0.08 & 0.01 & 0.01 & 0.01 & 7.16 & 0.47 & 0.25 \\
\hline
\end{tabular}

Table 3: Summary of major oxide compositions of studied tourmaline samples from southwestern Nigeria

\begin{tabular}{|c|c|c|}
\hline Oxides & Range (\%) & Mean \pm S.D \\
\hline $\mathrm{SiO}_{2}$ & $44.14-93.28$ & $86.36 \pm 11.39$ \\
\hline $\mathbf{F e O}$ & $0.01-2.10$ & $0.76 \pm 0.71$ \\
\hline $\mathrm{CaO}$ & $0.01-54.99$ & $4.13 \pm 13.12$ \\
\hline $\mathbf{P}_{2} \mathrm{O}_{5}$ & $0.01-1.33$ & $0.12 \pm 0.30$ \\
\hline $\mathbf{M g O}_{\mathbf{g}}$ & $0.01-0.17$ & $0.02 \pm 0.05$ \\
\hline $\mathrm{TiO}_{2}$ & $0.01-0.08$ & $0.02 \pm 0.02$ \\
\hline $\mathrm{Al}_{2} \mathrm{O}_{3}$ & $0.57-12.69$ & $7.80 \pm 2.71$ \\
\hline $\mathrm{Na}_{2} \mathrm{O}$ & $0.04-1.14$ & $0.60 \pm 0.26$ \\
\hline $\mathrm{K}_{2} \mathrm{O}$ & $0.05-0.52$ & $0.19 \pm 0.09$ \\
\hline
\end{tabular}


$\mathrm{CaO}$ is negatively correlated with all the other oxides except $\mathrm{TiO}_{2}$ with which it is positively correlated (Table 4). Strong negative correlation coefficients were obtained between $\mathrm{CaO}$ and the oxides $\mathrm{Al}_{2} \mathrm{O}_{3}(-0.62), \mathrm{Na}_{2} \mathrm{O}(-0.56), \mathrm{K}_{2} \mathrm{O}(-0.42)$ and $\mathrm{SiO}_{2}(-$ 0.97), clearly revealing features of magmatic deposits for the southwestern Nigerian tourmalines. The strong negative correlation that existed between $\mathrm{CaO}$ and $\mathrm{Al}_{2} \mathrm{O}_{3}$ on one hand and $\mathrm{SiO}_{2}$ and $\mathrm{CaO}$ on the other indicated magmatic origin (Frondel and Collette, 1957). Other pairs of oxides with strong to moderate negative correlations included $\mathrm{SiO}_{2}-\mathrm{TiO}_{2}(-0.69)$, $\mathrm{Al}_{2} \mathrm{O}_{3}-\mathrm{TiO}_{2}(0.37), \mathrm{K}_{2} \mathrm{O}-\mathrm{TiO}_{2}(-0.33)$ and $\mathrm{K}_{2} \mathrm{O}-\mathrm{TiO}_{2}(-0.33)$, all of which might be related to cations substitutions in the tourmaline structure, the higher the negative correlation coefficients, the greater the ease with which substitutions take place between the concerned cations. $\mathrm{Al}_{2} \mathrm{O}_{3}$ is positively correlated with the oxides $\mathrm{Na} 2 \mathrm{O}, \mathrm{FeO}, \mathrm{K}_{2} \mathrm{O}$ and $\mathrm{SiO}_{2}$ but negatively correlated with the others. Very strong positive correlation coefficients were established among the oxide pairs; $\mathrm{Al}_{2} \mathrm{O}_{3}-\mathrm{Na}_{2} \mathrm{O}(.91)$ and $\mathrm{Al}_{2} \mathrm{O}_{3}-\mathrm{FeO}$ (.78), while the oxide pairs $\mathrm{Al}_{2} \mathrm{O}_{3}-\mathrm{K}_{2} \mathrm{O}(.49)$ and $\mathrm{Al}_{2} \mathrm{O}_{3}-\mathrm{SiO}_{2}(0.42)$ exhibit moderate positive correlations.

Binary plots of some oxide pairs of the southwestern Nigerian tourmalines revealed compositional variations, mineralization trends, and suggest geochemical tools for future geochemical sampling procedures. There are discernable positive correlations between $\mathrm{Al}_{2} \mathrm{O}_{3}$ and $\mathrm{Na}_{2} \mathrm{O}$ (Fig. 5), $\mathrm{Al}_{2} \mathrm{O}_{3}$ versus $\mathrm{K} 2 \mathrm{O}$ (Fig. 6), $\mathrm{Al}_{2} \mathrm{O}_{3}$ against $\mathrm{FeO}$ (Fig. 7) and FeO versus $\mathrm{Na} 2 \mathrm{O}$ (Fig. 8), all yielding well-defined trends. The positive correlation between $\mathrm{Al}_{2} \mathrm{O}_{3}$ and the alkaline, $\mathrm{Na}_{2} \mathrm{O}$ and $\mathrm{K}_{2} \mathrm{O}$ is in line with the belief of $\mathrm{Morgan}$ and London (1989) that the solubility of aluminosilicates phases and components (e.g., Al) in borate fluids increases with increasing fluid alkalinity and may be indicative of changing speciation mechanisms in solution as a function of PH. The activity of $\mathrm{Al}_{2} \mathrm{O}_{3}$ or equivalent aqueous species also contributes to tourmaline stability and formation, which are favored in acidic fluids with high availability of $\mathrm{Al}$ species. However, since Al transport is facilitated by alkali borate species such as $\mathrm{Na}_{2} \mathrm{~B}_{4} \mathrm{O}_{7}$, a mixture of acidic and alkaline boron compounds is essential to provide the necessary $\mathrm{Al}$ for tourmaline-forming reactions (Morgan and London, 1989).A ternary plot of $\mathrm{Al}_{2} \mathrm{O}_{3}-\mathrm{FeO}-\mathrm{MgO}$ (Fig. 9) showed that all the analyzed tourmaline samples from southwestern Nigeria plot in the alumina zone, indicating that the tourmalines are alumina rich. Since tourmaline chemistry reflects the diverse compositions of host rock (Demirel et al., 2004), it therefore follows that the pegmatites housing the southwestern Nigeria tourmalines have per aluminous provenance and are formed within high to weak acidic environments. However, a remarkable feature noted in the majority of tourmalines from southwestern Nigeria is the direct positive relationship between total $\mathrm{FeO}$ and $\mathrm{Al}_{2} \mathrm{O}_{3}$. In other studies, the transition from $\mathrm{Al}$-rich to Fe-rich compositions has been linked to increasing distance from a magmatic source coincident with decreasing temperature and increasing differentiation of late magmatic fluids (Caverretta and Puxeddu, 1990).

Table 4: Statistical correlation coefficients for major oxides of tourmaline samples from different locations in southwestern Nigeria

\begin{tabular}{|c|c|c|c|c|c|c|c|c|c|}
\hline & $\mathrm{FeO}$ & $\mathrm{CaO}$ & $\mathrm{P}_{2} \mathrm{O}_{5}$ & $\mathrm{MgO}$ & $\mathrm{TiO}_{2}$ & $\mathrm{Al}_{2} \mathrm{O}_{3}$ & $\mathrm{Na}_{2} \mathrm{O}$ & $\mathrm{K}_{2} \mathrm{O}$ & $\mathrm{SiO}_{2}$ \\
\hline $\mathrm{FeO}$ & 1 & & & & & & & & \\
\hline $\mathrm{CaO}$ & -0.27 & 1 & & & & & & & \\
\hline $\mathrm{P}_{2} \mathrm{O}_{5}$ & -0.29 & -0.10 & 1 & & & & & & \\
\hline $\mathrm{MgO}$ & $.49^{*}$ & -0.15 & -0.16 & 1 & & & & & \\
\hline $\mathrm{TiO}_{2}$ & -0.13 & $.69^{* *}$ & -0.19 & 0.09 & 1 & & & & \\
\hline $\mathrm{Al}_{2} \mathrm{O}_{3}$ & $.78^{* *}$ & $.62^{* *}$ & -0.35 & 0.27 & -0.37 & 1 & & & \\
\hline $\mathrm{Na}_{2} \mathrm{O}$ & $.82^{* *}$ & $-.56^{* *}$ & -0.12 & 0.34 & -0.22 & $.91^{* *}$ & 1 & & \\
\hline $\mathrm{K}_{2} \mathrm{O}$ & 0.21 & -0.42 & -0.17 & 0.08 & -0.33 & $.49^{*}$ & 0.35 & 1 & \\
\hline $\mathrm{SiO}_{2}$ & 0.05 & $-.97^{* *}$ & 0.20 & 0.07 & $-.69^{* *}$ & 0.42 & 0.35 & 0.34 & 1 \\
\hline
\end{tabular}

${ }^{*}$ Correlation is significant at the 0.05 level (2-tailed)

** Correlation is significant at the 0.01 level (2-tailed)

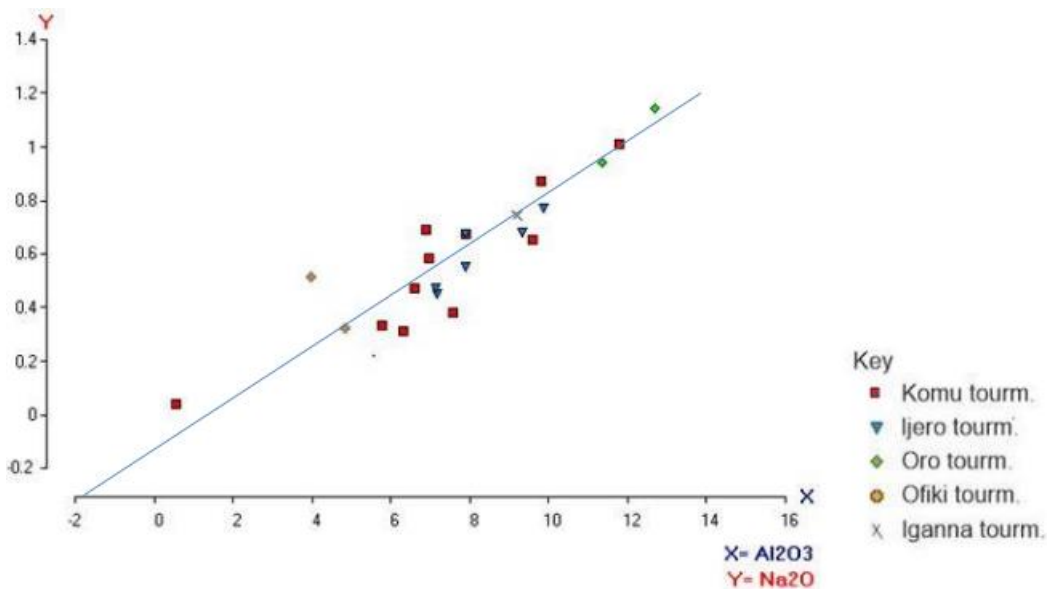

Figure 5: Correlation plot of $\mathrm{Al}_{2} \mathrm{O}_{3}$ and $\mathrm{Na}_{2} \mathrm{O}$ for southwestern tourmalines 


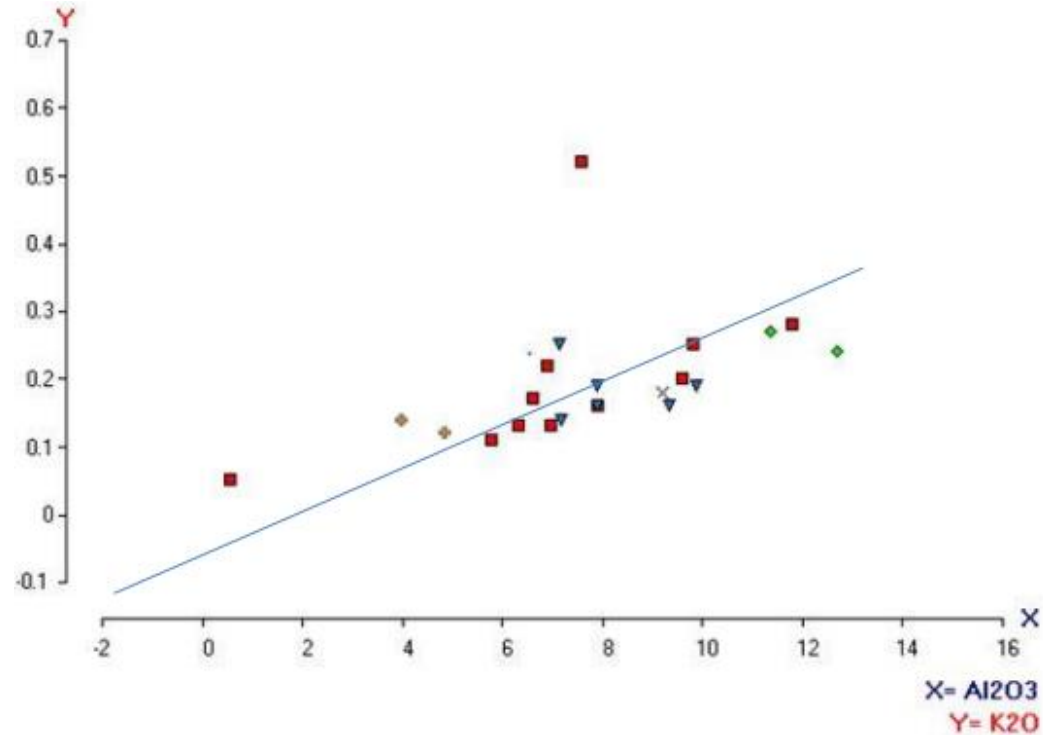

Key

- Komu tourm.

v ljero tourm.

- Oro tourm.

- Ofiki tourm

$x$ Iganna tourm

Figure 6: A binary plot of $\mathrm{Al}_{2} \mathrm{O}_{3}$ and $\mathrm{K}_{2} \mathrm{O}$ for southwestern tourmalines
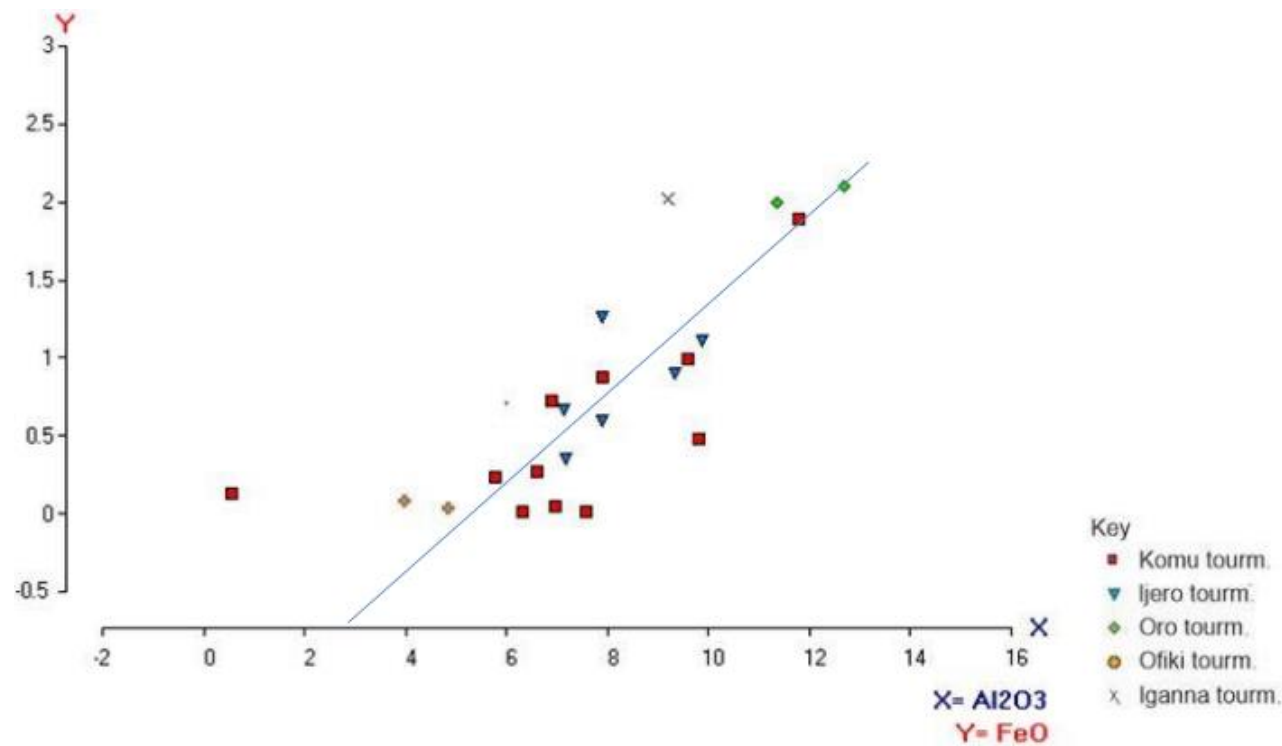

Figure 7: A binary plot of $\mathrm{Al}_{2} \mathrm{O}_{3}$ and $\mathrm{FeO}$ for southwestern tourmalines

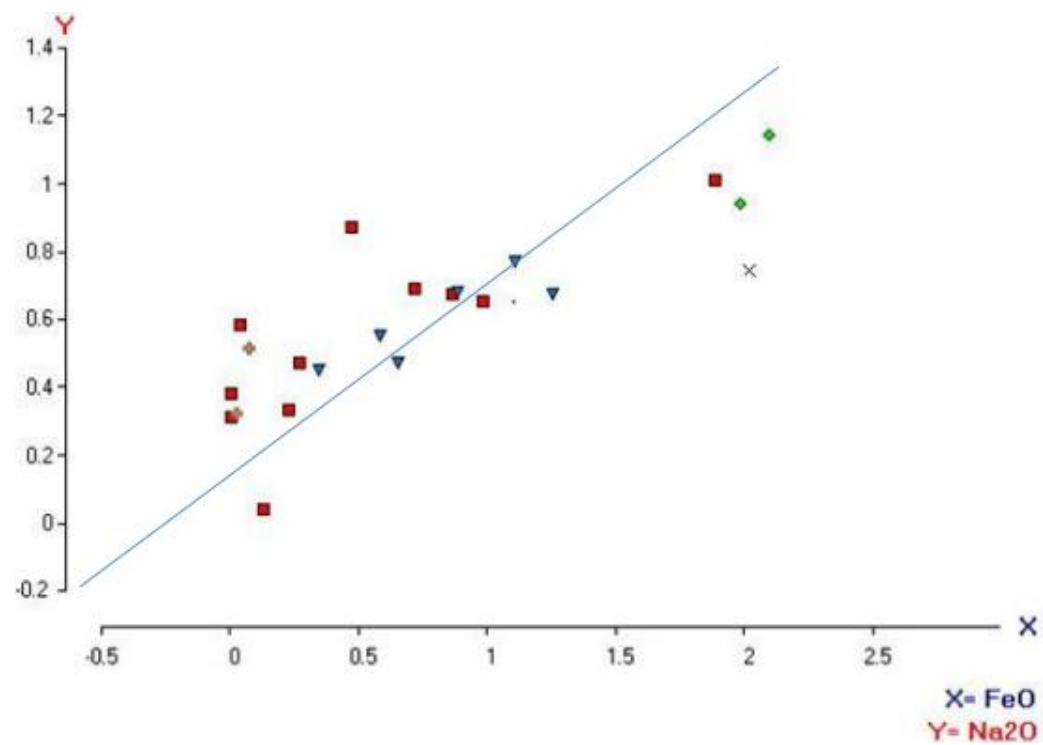

Key

- Komu tourm

$\nabla$ ljero tourm.

- Oro tourm.

- Ofiki tourm.

x Iganna tourm.

Figure 8: A correlation plot of $\mathrm{FeO}$ and $\mathrm{Na}_{2} \mathrm{O}$ for southwestern tourmalines 


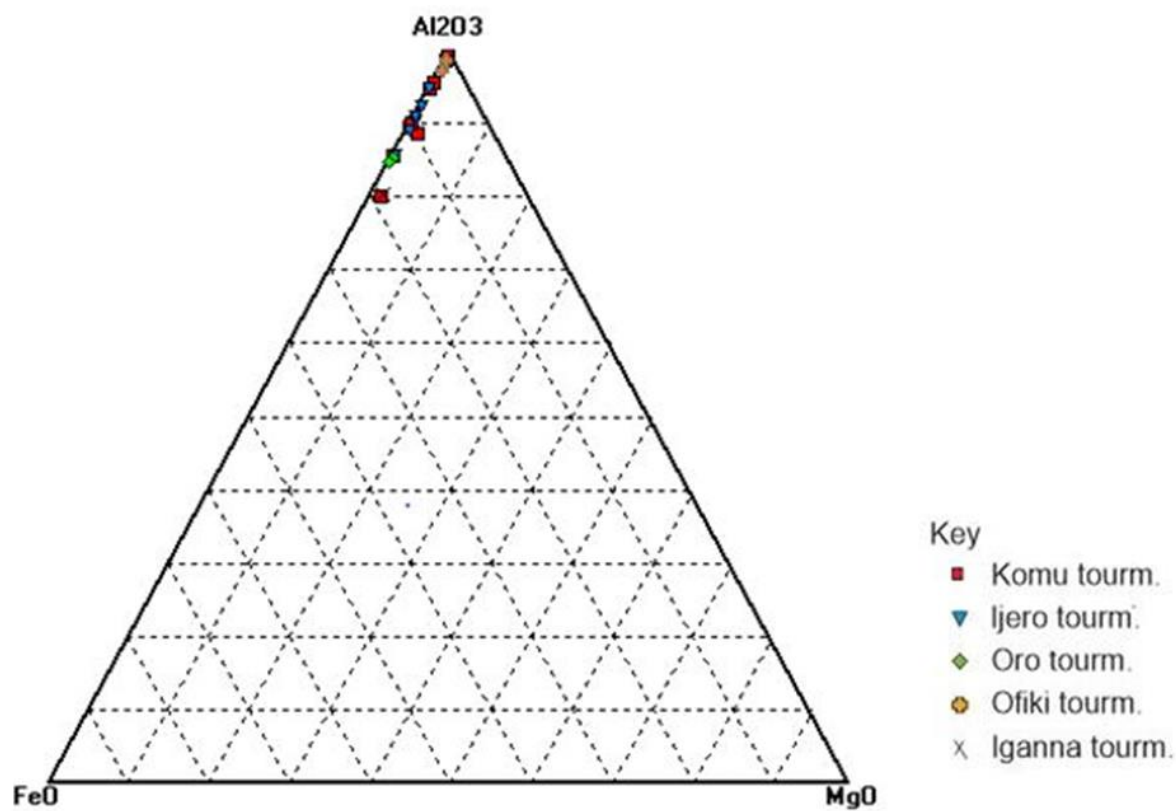

Figure 9: $\mathrm{Al}_{2} \mathrm{O}_{3}-\mathrm{FeO}-\mathrm{MgO}$ ternary diagram for southwestern tourmalines

The oxides $\mathrm{MgO}, \mathrm{TiO}_{2}$ and $\mathrm{P}_{2} \mathrm{O}_{5}$ have each consistently exhibited either negative or very low positive values of correlation coefficients with all the other oxides except the oxide pairs $\mathrm{FeO}-\mathrm{MgO}(.49)$ and $\mathrm{CaO}-\mathrm{TiO}_{2}(.69)$ which showed significant positive correlations (Table 4). The level of affinity among the cations in the respective pairs is indicated by the degree of positive correlation. The positive correlation that existed between $\mathrm{FeO}$ and $\mathrm{MgO}$ may presumably suggest uvite substitutions in the tourmaline samples and chemical influence of the mafic host country rocks that are prevalent in almost all the tourmaline environments in southwestern Nigeria. Dunn (1977) however reported that $\mathrm{MgO}$ would not cause a color change, but would have an influence on the presence or otherwise and amount of other oxides/elements. The non-reactive nature of $\mathrm{P}_{2} \mathrm{O}_{5}$ is exhibited by its consistently low positive or negative values of correlation coefficients with all the other oxides.

The major elements composition of the southwestern Nigerian tourmaline samples (Fig. 5) exhibits distinct variations reflecting the environment of formation. The composition and therefore mineralogy of tourmalines are virtually dictated by the mineralizing fluid and the environment of deposition, particularly the host rocks' chemistry. Thus comparing modeled and measured tourmaline compositions provides information on the conditions prevailing in its host environment. The host rock lithologies of the southwestern Nigerian tourmaline samples correlate well with the pre-defined fields in the Al-Fe-Mg and Ca-Fe-Mg plots (Fig. 10 and 11) of Henry and Guidotti (1985). All the tourmaline samples fall into the fields of Li-rich granitoid pegmatites and aplites of the Al-Fe-Mg plot (Fig 10) of Henry and Guidotti (1985) and majority of the samples also plot in the Ca-Fe-Mg plot (Fig. 11) of Henry and Guidotti (1985), except only three that have plotted in the Li-poor granitoids and associated pegmatites and aplites. It therefore follows that the southwestern Nigerian tourmalines are pegmatitic in origin, and this is also confirmed by the relatively high $\mathrm{Fe} / \mathrm{Fe}+\mathrm{Mg}$ ratio, averaging 0.89 .

Table 5: Major element compositions (\%) of studied tourmaline samples from southwestern Nigeria

\begin{tabular}{|c|c|c|c|c|c|c|c|c|c|c|c|c|}
\hline & & & $\mathrm{Fe}$ & $\mathrm{Ca}$ & $P$ & $M g$ & $T i$ & $A l$ & $\mathrm{Na}$ & $K$ & $S$ & $\mathrm{Fe} / \mathrm{Fe}+\mathrm{Mg}$ \\
\hline Sample & Sample source & Sample colour & & & & & & & & & & \\
\hline$M 001$ & Komu & Pink & 0.01 & 0.04 & 0.007 & 0.01 & 0.005 & 3.35 & 0.233 & 0.11 & 0.02 & 0.5 \\
\hline M002 & Komu & Pinkish red & 0.01 & 0.05 & 0.015 & 0.01 & 0.008 & 4.02 & 0.283 & 0.43 & 0.02 & 0.5 \\
\hline M003 & Komu & Green & 0.68 & 0.22 & 0.099 & 0.01 & 0.011 & 4.18 & 0.498 & 0.13 & 0.02 & 0.99 \\
\hline M004 & Komu & Blue & 0.1 & 39.31 & 5.000 & 0.01 & 0.071 & 0.3 & 0.027 & 0.04 & 0.02 & 0.91 \\
\hline M005 & Komu & Yellow & 0.03 & 0.01 & 0.001 & 0.01 & 0.06 & 3.69 & 0.432 & 0.11 & 0.02 & 0.75 \\
\hline M006 & Komu & Lemon yellow & 0.21 & 0.07 & 0.003 & 0.01 & 0.008 & 3.51 & 0.347 & 0.14 & 0.02 & 0.95 \\
\hline M007 & Komu & Dark blue & 1.47 & 0.05 & 0.003 & 0.06 & 0.015 & 6.24 & 0.752 & 0.23 & 0.02 & 0.96 \\
\hline M008 & Ofiki & Purple & 0.06 & 1.02 & 0.58 & 0.01 & 0.008 & 2.12 & \begin{tabular}{|l|}
0.38 \\
\end{tabular} & 0.12 & 0.02 & 0.86 \\
\hline$M 009$ & Komu & Yellow green & 0.56 & 0.14 & 0.007 & 0.07 & 0.036 & 3.66 & 0.511 & 0.18 & 0.02 & 0.89 \\
\hline M010 & Komu & Brown & 0.37 & 0.28 & 0.094 & 0.01 & 0.029 & 5.2 & 0.647 & 0.21 & 0.02 & 0.97 \\
\hline M011 & Komu & Green & 0.77 & 0.29 & 0.002 & 0.01 & 0.017 & 5.08 & 0.484 & 0.17 & 0.02 & 0.99 \\
\hline
\end{tabular}




\begin{tabular}{|l|l|l|l|l|l|l|l|l|l|l|l|l|}
\hline M012 & Komu & Grey & 0.18 & 22.16 & 5.000 & 0.01 & 0.046 & 3.07 & 0.248 & 0.09 & 0.02 & 0.95 \\
\hline M013 & Ofiki & Orange & 0.02 & 0.61 & 0.223 & 0.01 & 0.014 & 2.58 & 0.236 & 0.1 & 0.02 & 0.67 \\
\hline M014 & Ijero & Green blue & 0.98 & 0.03 & 0.009 & 0.01 & 0.005 & 4.2 & 0.494 & 0.13 & 0.02 & 0.99 \\
\hline M015 & Ijero & Light blue & 0.27 & 0.09 & 0.005 & 0.01 & 0.004 & 3.81 & 0.336 & 0.12 & 0.02 & 0.96 \\
\hline M016 & Ijero & Green & 0.86 & 0.09 & 0.004 & 0.03 & 0.011 & 5.23 & 0.568 & 0.16 & 0.02 & 0.97 \\
\hline M017 & Ijero & Yellow green & 0.69 & 0.13 & 0.015 & 0.03 & 0.017 & 4.96 & 0.503 & 0.13 & 0.02 & 0.96 \\
\hline M018 & Ijero & Green blue & 0.46 & 0.11 & 0.028 & 0.01 & 0.007 & 4.2 & 0.411 & 0.16 & 0.02 & 0.98 \\
\hline $\mathbf{M 0 1 9}$ & Oro & Dark blue & 1.63 & 0.05 & 0.003 & 0.01 & 0.014 & 6.72 & 0.847 & 0.2 & 0.02 & 0.99 \\
\hline $\mathbf{M 0 2 0}$ & Oro & Dark green & 1.55 & 0.1 & 0.003 & 0.01 & 0.023 & 6.02 & 0.699 & 0.22 & 0.02 & 0.99 \\
\hline $\mathbf{M 0 2 1}$ & Iganna & Black & 1.57 & 0.06 & 0.012 & 0.1 & 0.027 & 4.87 & 0.552 & 0.15 & 0.02 & 0.94 \\
\hline $\mathbf{M 0 2 2}$ & Ijero & Blue & 0.51 & 0.06 & 0.004 & 0.01 & 0.009 & 3.79 & 0.348 & 0.21 & 0.02 & 0.98 \\
\hline
\end{tabular}

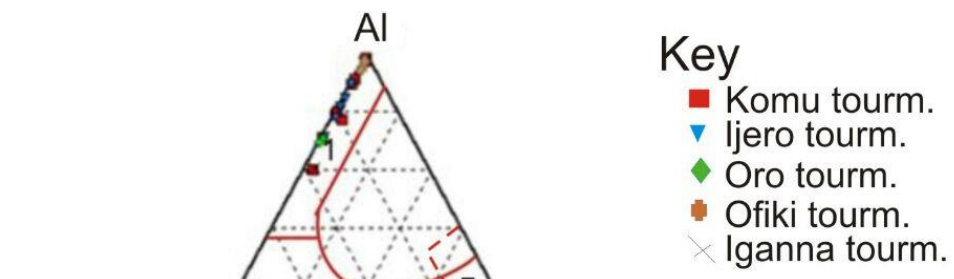

$1 \mathrm{Li}$-rich granitoids pegmatites and aplites

$2 \mathrm{Li}$-poor granitoids and their associated pegmatites and aplites $3 \mathrm{Fe}^{3+}$-rich quartz-tourmaline rocks 4 Metapelites \& metapsammites coexisting with an Al-saturating phase 5 Metapelites \&metasammites not coxisting with an Al-saturating phas $6 \mathrm{Fe}^{3}$-rich quart-tourmaline rocks, calc-silicate rocks and metapelites 7 Low-Ca metaultramafic rocks and cr, v-rich metasedimentary rocks 8 Metacarbonates and metapyroxenites

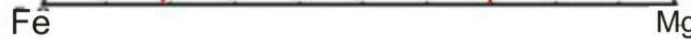
$\mathrm{Mg}$

Figure 10: Al - Fe - Mg ternary plot of the southwestern Nigerian tourmalines (After Henry and Guidotti (1985))

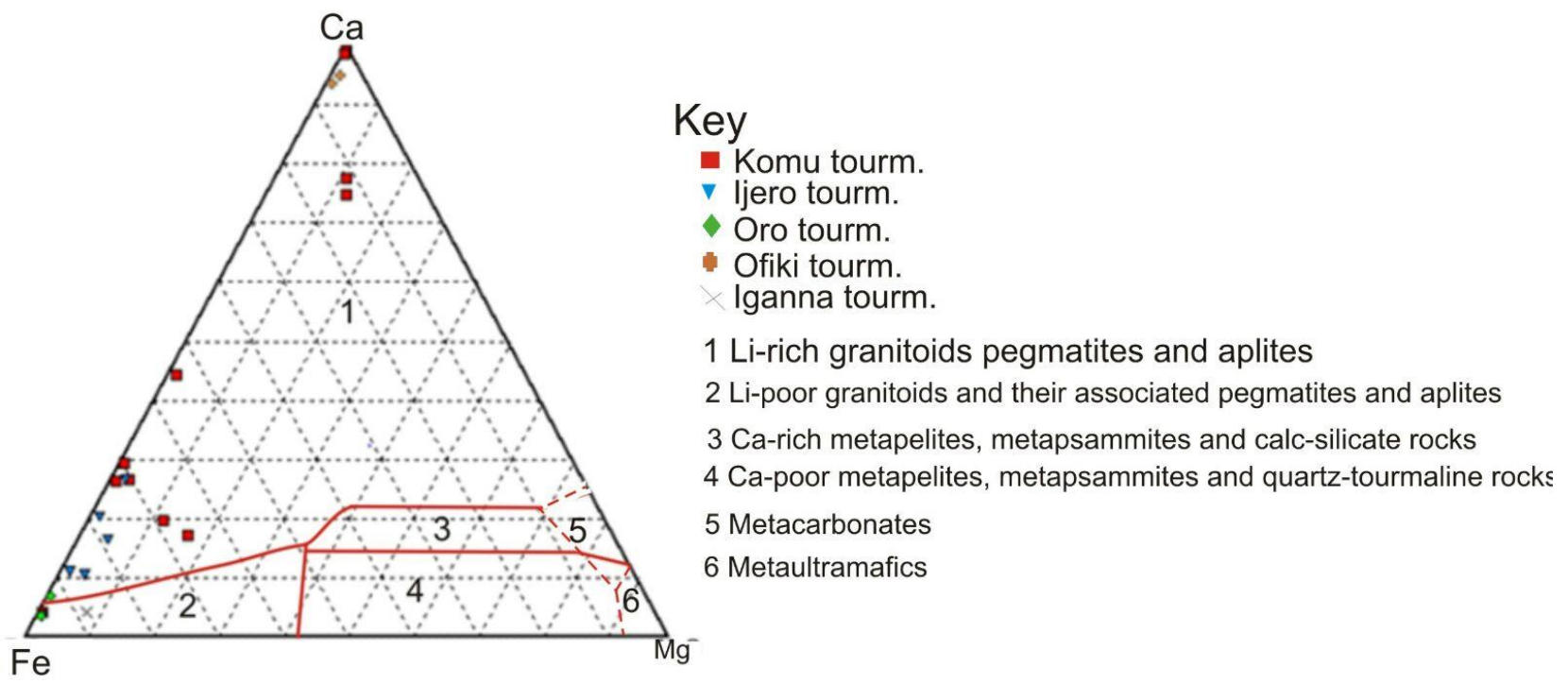

Figure 11: Ca- Fe - Mg ternary plot of the southwestern Nigerian tourmalines (After Henry and Guidotti (1985))

\section{CONCLUSION}

The southwestern Nigerian tourmalines showed wide compositional variability particularly in the oxidesSiO $2, \mathrm{CaOand}$ $\mathrm{Al}_{2} \mathrm{O}_{3}$, resulting from the compositional heterogeneity of the mineralizing fluids and diversity in geologic settings and chemistry of the host rock environments of crystallization of the tourmalines. The inverse correlations existing between $\mathrm{CaO}$ and the oxides $\mathrm{Al}_{2} \mathrm{O}_{3}, \mathrm{Na}_{2} \mathrm{O}, \mathrm{K}_{2} \mathrm{O}$ and $\mathrm{SiO}_{2}$, clearly reveal features of magmatic deposits for the southwestern Nigerian tourmalines. A ternary plot of $\mathrm{Al}_{2} \mathrm{O}_{3}-\mathrm{FeO}-\mathrm{MgO}$ showed that the southwestern Nigeria tourmalines are 
alumina-rich, indicating per aluminous provenances for their host rocks, which also have lithologies correlating well with the pre-defined field of Li-rich granitoids pegmatites and aplites of the Al-Fe-Mg and Ca-Fe-Mg plots of Henry and Guidotti (1985).The relatively high $\mathrm{Fe} / \mathrm{Fe}+\mathrm{Mg}$ ratio, averaging 0.89 also confirms pegmatitic origin for these tourmalines. The abundance of tourmaline and lack of significant amounts of other borosilicates in most of the gemstones deposits of Southwestern Nigeria is indicative of acidic fluids with high Al activities and sufficient ferromagnesian components necessary for tourmaline crystallization and formation. The results of the geochemical analysis of the southwestern tourmalines also established that the $\mathrm{FeO}$ content varies directly and proportionately with the depth of color in the greens, and inversely in the pinks and reds, being totally absent, or, if present, only in extremely minute traces in the reds. The southwestern Nigerian tourmalines are magmatic in origin occurring in miarolitic cavities within pegmatites and along the contacts which these pegmatites have made with their host rocks.

\section{REFERENCES}

Adetunji, A., Olarewaju, V. O.,Ocan, O. O., Ganev, V. Y. and Macheva, L. 2016.Geochemistry and U-Pb zircon geochronology of the pegmatites inEde area, southwestern Nigeria: A newly discovered oldest Pan Africanrock in southwestern Nigeria. Journal of African Earth Sciences 115, 177-190

Akande, S. O. and Reynolds, P. H. 1990. ${ }^{40} \mathrm{Ar} /{ }^{39} \mathrm{Ar}$ spectrum ages of micas from the Sn-Nb-Ta bearing pegmatites in Nigeria. In: Proceeding, Volume 15, Colloquium of African Geology. Centre International Pour la Formation Et les EchangesGeologiques (CIFEG) Occassional Publication 1990/20 p243.

Annor, A. E., Olobaniyi, S. B. and Mucke, A. 1996. A note on the geology of the Isanlu area in the Egbe-Isanlu Schist Belt, S. W. Nigeria. Journal of Mining and Geology.32(1)47-51

Annor, A.E. 1995. U-Pb zircon age for the Kabba-Okene granodiorite gneiss:implication for Nigeria's basement chronology. Afr. Geosci. Rev. 2, 101-105.

Ball, E. 1980. An example of very consistent brittle deformation over a wide intra-continental area: The late Pan-African Fracture system of the Tuareg and Nigerian Shield. Tectonophys 61,363-379.

Black, R. 1980. Precambrian of West Africa, Episodes, 4, 3-8.

Cavarretta, G. and Puxeddu, M. 1990. Schorl-dravite-ferridravite tourmalines deposited by hydrothermal magmatic fluids during early evolution of the Larderello geothermal field, Italy. Economic Geology. 85 (6), 1236-1251.

Dada, S. S., Lancelot, J. R. and Briqueu, I. 1987. Age and origin of a Pan-African charnockitic complex: U-Pb and Rb-Sr evidence from the charnockitic complex at Toro, Northern Nigeria. Abtr. Vol. 14 Coll. Afri. Geol. Berlin, 72-73.

Dada, S.S. 2006. Proterozoic Evolution of Nigeria. In: The Basement Complex of Nigeria and its Mineral Resource. Oshin, O. Ed. Akin Jinad and Co. Ibadan, Nigeria, pp24 - 44.

Dada, S.S., 1998. Crust-forming ages and Proterozoic crustal evolution in Nigeria: areappraisal

Deer W.A, Howie R.A. and Zussmam, J. 1966. An introduction to the rock-forming minerals. ${ }^{\text {nd }}$ ed. London: Longman group ltd. 696p.

Demirel, S. 2004. Origin and significance of a quartz tourmaline breccia zone within the central Anatolian crystalline complex, Turkey. M.Sc project. Dept. of geological engineering. Middle East technical university. Xv + 111pp.

Dunn, P. J. 1977. Elbaite from Newry, maine. Mineralogical Record, 6:22-25

Ekwueme, B. N. and Matheis, G. 1995. Geochemistry and economic value of pegmatites in the Pre-cambrian basement of Southeast Nigeria. In: Magmatism in relation to diverse tectonic settings. Srivastava, R. K. and Chandra, R. eds. IBH Publishing Co., New Delhi, India, 375-392pp.

Elueze, A. A. 1992. Rift system for Proterozoic schist belts in Nigeria. Tectonophysics.209 167-169.

Elueze, A. A. 2000. Compositional appraisal and petrotectonic significance of Imelu banded ferruginous rock in the Ilesha schist belt south western Nigeria. Journ. Min. Geol. 36(1). 9-18.

Frondel, C., and Collette, R. L. 1957. Synthesis of toumaline by reaction of mineralgrains with $\mathrm{NaCl}-\mathrm{H} 3 \mathrm{BO} 3$ solution, and its implications in rock metamorphism. American Mineralogist, 42, 754-758.

Garba, I. 1992. Geology, geochemistry and origin of gold mineralization at Bin Yauri, Nigeria. PhD Thesis, University of London, UK. 264pp.

Garba, I. 2003. Geochemical discrimination of newly discovered rare-metal bearing and barren pegmatites in the Pan-African $(600 \pm 150 \mathrm{Ma})$ basement of northern Nigeria. Applied Earth Science (Trans. Inst. Min. Metall.) 112; 287-292.

Grant, N. K. 1969. The late Precambrian to Early Paleozoic Pan- African orogeny in Ghana, Togo, Dahomey and Nigeria. Bull Geol. Soc. Amer. Vol. 50 pp. $45-56$.

Grew, E. S. 1996. Borosilicates (exclusive of tourmaline) and boron in rock-forming minerals in metamorphic environments. Reviews in Mineralogy, 33, 387-502.

Harper, C. T., Sherrer. G., McCurry, P. and Wright, J. B. 1973. K-Ar retention ages from the Pan- African of Northern Nigerian, Bull. Geol. Soc. Amer. Pp. 919 - 926.

Hawthorne, F. C, McDonald, D.J., Burns, P.C., 1993. Reassignment of cation site occupancies in tourmaline: AI-Mg disorder in the crystal structure of dravite. American Mineralogist, 78, 265-270. 
Hawthorne, F. C. and Henry, D. J. 1999. Classification of the minerals of the tourmaline group. European Journal of Mineralogy, 11, 201-215.

Henry, D.J. and Guidotti, C. V. 1985. Tourmaline as a petrogenetic indicator mineral: an example from the staurolite-grade metapelites of NW Maine. American mineraogistl.70,1-15.

Jacobson, R.R. E and Webbs, J. S. 1946. The pegmatites of central Nigeria. Geol. Surv. Nigeria Bull. 17, 66p.

Kabata-Pendias, A. 2001. Trace elements in soils and plants. $3^{\text {rd }}$ ed. CRS press. NY.

Kuster, D. 1990. Rare-metal pegmatites of Wamba, Central Nigeria-their formation in relationship to late Pan-African granites. Mineral Deposita25, 25-33.

Macdonald, D.J., Hawthorne, F.C. and Grice, J.D. 1993.Foitite, a new alkali deficient tourmaline: description and crystal structure. Am. Mineral. 78, 1299-1303.

Matheis, G. and Caen-Vachette, M. 1983. Rb-Sr isotopic study of rare-metal bearing and barren pegmatites in the Pan-African reactivation zone of Nigeria. J. Afr. Ear. Sci. 1, 35-40.

Morgan, G. B. and London, D. 1989. Experimental reactions of amphibolite with boron-bearing aqueous fluids at 200 MPa: implications for tourmaline stability and partial melting in mafic rocks. Contributions to Mineralogy and Petrology, 102, $281-297$.

Obaje, N.G. 2009. Geology and Mineral Resources of Nigeria. Lecture Notes in Earth Sciences. 120, DOI 10.1007/978-3-540-92685-6 2.

of current interpretations. Precambrian Res. 87, 65-74.

Okonkwo, C.T., Ganev, V.Y., 2012. U-Pb zircon geochronology of the Jebba granitic gneiss and its implications for the Paleoproterozoic evolution of Jebba area, southwestern Nigeria. Int. J. Geosci. 3, 1065-1073.

Olarewaju, V. O. 1999. Fluid inclusion studies of Coarse- grained Charnockitic and hybrid rocks in Ukpilla area, Southwestern Nigeria. Joun. Min. Geology 35 (1) pp 1-8.

Oversby, V. M. 1975. Lead Isotope study of aplites from the Precambrian basement rocks near Ibadan, Southwestern Nigeria. Earth Planets, Sci. Lett. 27, pp177 - 180.

Parkin, K. M., Loeffler, B. M., and Burns, R. G. 1977. Mössbauer spectra of kyanite, aquamarine, and cordierite showing intervalence charge transfer. Physics and Chemistry of Minerals. 1(3), 301-311

Pezzotta, F. and Laurs, B. M. 2011. Tourmaline: The kaleidoscopic gemstone. Elements 7: 333-338.

Platonov, A. N., Langer, K., Chopin, C., Andrut, M., and Taran, M. N. 2000. Fe ${ }^{2+}-\mathrm{Ti}^{4+}$ charge-transfer in dumortierite. European Journal of Mineralogy. 12 (3), 521-528.

Rahaman, M. A. and Ocan O. 1978. On relationships in the Precambrian Migmatite-gneisses of Nigeria. Niger J Min Geol 15:23-32.

Rahaman, M. A., Ajayi, T. R., Oshin, I. O., and Asubiojo, F. O. 1988. Trace elements Geochemistry and geotectonic setting of IfeIlesha schist belts. Precambrian Geology of Nigeria. GNS Publications. Kaduna., pp241-256.

Rahaman, M. A., Emofurieta, W. D.and Caen-Vachette, M. 1983. The potassic granites of the Igbeti area: Further evidence of the polycyclic evolution of the Pan-African belt in South Western Nigeria. Precamb. Res. 22, 27-92.

Rahaman, M.A. 1988. Recent advances in the study of the basement complex of Nigeria. In: Oluyide, P.O., Mbonu, W.C., Ogezi, A.E.,Egbuniwe, I.G., Ajibade, A.C., Umeji, A.C. (Eds.).Precambrian Geology of Nigeria. Geological Survey of Nigeria Special Publication. pp. 11-41.

Selway, J.B., Novák, M., Hawthorne, F.C., Černý, P., Ottolini, L. and Kyser, T.K. 1998.Rossmanite, $\square(\mathrm{Li}, \mathrm{Al} 2) \mathrm{Al} 6 \mathrm{Si} 6 \mathrm{O} 18(\mathrm{BO}) 3(\mathrm{OH}) 3(\mathrm{OH})$, a new alkali deficient tourmaline; description and crystal structure. Am. Mineral. 83, 896-900.

Slack, J. F. 1996. Tourmaline associations with hydrothermal ore deposits. Boron mineralogy, petrology and geochemistry. E.S. Grew and L.N. Anovitz. Eds. Reviews in Mineralogy. 33. 559-643.

Turner, D. C. 1983. Upper Proterozoic schist belts in the Nigerian sector of the Pan-African province of West Africa. Precambrian Research, 21, 55-79.

Umeji, A. C. and Caen-Vachette, M.1984. Geochronology of Pan-Africa Nasarawa Eggon and MkarGboko granites, South East Nigeria. Precambr. Res. 23, 317-324.

Van Breemen, O., Pidgeon, R. T. and Bowden, P. 1977. Age and isotopic studies of Pan-African granites from North-Central Nigeria.Precambr. Res. 4, 307-319.

Wright, J. B. 1970. Controls of mineralization in the Older and Younger tin fields of Nigeria. Economic Geology. 65:945-951.

$$
--0 \text {-- }
$$

